\title{
Research on Social Entrepreneurship Based on the Dual Perspective of Empathy and Impromptu Behavior
}

\author{
Tiannan Yang ${ }^{1, a,{ }^{*}}$, Xiaoyuan $\mathrm{Li}^{1, \mathrm{~b}}$ \\ ${ }^{1}$ Business School, Jiangxi Normal University, Nanchang, China \\ ayangtiannan123@163.com, 'lihappy0791@163.com \\ ${ }^{*}$ Corresponding author
}

Keywords: Prior Experience, Empathy, Improvisation, Social Entrepreneurship.

\begin{abstract}
Social entrepreneurship is a special form of entrepreneurship. It is a mixed organization type that takes into account both commercial and public welfare. Social entrepreneurship is of great significance to social development, and its development has caused extensive discussion in the academic circles. Based on this, this paper sorts out the related concepts of social entrepreneurship and the influence of prior experience on social entrepreneurial behavior, and the mediating effect of empathy and improvisation between social entrepreneurship and prior experience. I hope that through the research conclusions of this paper, we can expand the antecedents of social entrepreneurship and promote the development of social entrepreneurship.
\end{abstract}

\section{Introduction}

Volkswagen Entrepreneurship and Innovation is the dual engine of the economic development proposed by the Chinese government to promote the sound development of the economy. However, attaching importance to economic entrepreneurship and ignoring social entrepreneurship, and not linking economic entrepreneurship with social entrepreneurship are prominent problems in the current mass entrepreneurship process [1]. Encouraging entrepreneurs to conduct social entrepreneurship has great significance for a better development of national enterprises. Social entrepreneurship has received widespread attention by delivering public services and public value in a profit-making way [2].

By studying the relevant literature, we find that domestic research on social entrepreneurship is only focused on the definition of concepts and the summary stage of literature review [3]. This article sorts out social entrepreneurship on the basis of the connotation and related literature, and puts forward the influence of previous experience on social entrepreneurship and the mediating role of impromptu behavior and empathy. I hope to further improve the research of social entrepreneurship through this paper.

\section{Literature review}

\subsection{Social Entrepreneurship}

Social entrepreneurship is a social movement that emerged in the process of globalization, with the combination of political, economic and social changes [4]. At the beginning, Leadbeater proposed in 1997 that social entrepreneurship refers to the use of entrepreneurial behavior to serve social goals, these services are not targeted at profit, but for specific vulnerable groups [5]. In the study of social entrepreneurship in China, many scholars have adopted the definition of Dorado: "Social entrepreneurship is to use entrepreneurship to solve social problems and achieve national growth and development" [6], which is the definition that this research based on.

\subsection{Prior Experience}

Prior experience refers to the information, knowledge, and skills acquired by entrepreneurs or potential entrepreneurs in past experiences [7]. According to the research of scholars the prior 
experience is generally divided into two categories: entrepreneurial experience, industry experience. Entrepreneurial experience refers to whether entrepreneurs have had experience related to entrepreneurial activities before starting an entrepreneurial activity [8]. Industry experience means that entrepreneurs have had relevant industry experience before starting a business, which has a positive effect on entrepreneurs' mastery of product design and technical knowledge [9].

\subsection{Empathy}

Empathy refers to feel other people's emotions from the perspective of the parties, thus generating sympathy and concern for those in need. It is an important variable for predicting pro-social behavior [10]. The empathy is generally divided into two dimensions of cognition and emotion. Cognitive factors refer to whether they can recognize the dilemma of others and whether they have the ability to think about problems from the other side's perspective. Emotional factors refer to whether they can respond in others' misfortune and feel the same for others' feelings [11].

\subsection{Improvisation}

Impromptu behavior first appeared in the fields of drama and music. In the 1990s, the field of organizational management continued to focus on the impact of impromptu behavior on organizational management processes. Due to the uncertainty of the modern management environment and the lack of resources, the impromptu behavior of managers has become an important solution to the organization's emergencies [12]. Best believe that improvisation is a real-time innovation activity initiated and implemented by a team, organization or the entire company[13].

\section{Research hypothesis}

\subsection{The impact of previous experience on social entrepreneurship}

In the field of entrepreneurship, entrepreneurs are more likely to obtain human capital and external resources in the previous entrepreneurial process, which makes entrepreneurs are more willing to participate in entrepreneurial activities, and enhance the willingness of entrepreneurs to start business again [14]. Previous experience can also refer to other aspects of entrepreneurial experience. Social entrepreneurship is a special type of entrepreneurial activity, mainly for solving social problems and caring for marginalized groups, therefore the willingness of social entrepreneurship will be more susceptible to work experience and life experience [15]. And some studies have shown that individual's willingness for social entrepreneurs relates to unemployment experience, poverty experience and social work experience [16]. Therefore, social entrepreneurs with the same experience or social entrepreneurs with entrepreneurial experience will be more likely to be more capable of conducting relevant social entrepreneurial behaviors. Therefore, this paper proposes the following assumptions:

H1: Previous experience has a positive impact on social entrepreneurial behavior.

\subsection{Mediating effect of empathy}

According to the theory of social comparison, downward comparison will raise people's empathy, and then Increasing people's general pro-social behavior [17]. Social entrepreneurs and recipients in need of help are in a downward-comparative relationship. When social entrepreneurs find someone in need of help, they are prone to have pro-social behavior and empathy, and then conduct social entrepreneurship behavior. Some studies have shown that entrepreneurs with many difficult life experiences are more likely to engage in social activities and solve social problems. Those unfavorable living environment makes it easier for entrepreneurs to empathize, understand the feelings of the recipients, which stimulate entrepreneurs to have social entrepreneurship [18]. Thus, this paper proposes the following assumption:

$\mathrm{H} 2$ : Empathy has a mediating role between prior experience and social entrepreneurial behavior. 


\subsection{Mediating effect of impromptu behavior}

Impromptu behavior first appeared in the fields of drama and music. In the 1990s, the field of organizational management continued to focus on the impact of impromptu behavior on organizational management processes. Due to the uncertainty of the modern management environment and the lack of resources, the impromptu behavior of managers has become an important solution to the organization's emergencies [12]. Best believe that improvisation is a real-time innovation activity initiated and implemented by a team, organization or the entire company [13].

\subsection{Improvisation}

Entrepreneurs with rich prior experience will be more effective in conducting entrepreneurship. Leybourne and Smith proposed in the study that the use of intuitive judgment has a positive effect on impromptu behavior, and also suggests the experience impacts on impromptu behavior in a positive way[19]. The accumulation of prior experience will help entrepreneurs to improvise and make positive feedback in the face of complex market conditions. On the other hand, the accumulation of prior industry experience in the process of social entrepreneurship can help entrepreneurs quickly acquire relevant strategic in the face of emergencies, and make effective and positive responses, which contribute to the effectiveness of their improvisation and persistence. Therefore, this paper proposes the following assumption:

H3: Impromptu behavior has a mediating effect between prior experience and social entrepreneurial behavior.

\section{Conclusion}

This paper explores the influence of prior experience on social entrepreneurial behavior, as well as the mediating role of empathy and improvisation, and expands the antecedents of social entrepreneurship, which is beneficial to the theoretical construction of social entrepreneurship to some extent. Furthermore, in the process of daily entrepreneurship education, we can also promote the development of social entrepreneurship by cultivating students' empathy.

The limitations of this paper are as follows: Firstly, this paper only verifies the influence of previous experience on social entrepreneurial behavior and the mediating role of empathy and improvisation on the theoretical level, and does not conduct empirical analysis. Secondly, there is no detailed dimensional division of previous experience. Hence, the empirical methods will be used to test whether the above theory holds in subsequent studies.

\section{Acknowledgment}

This research was financially supported by the Jiangxi Normal University Graduate Innovation Fund Project.

\section{References}

[1] Fu Ying, Si Xiaofu, Chen Hui, Social Entrepreneurship in the Context of China: Frontier Research and Suggested Questions, Foreign Economics \& Management, vol.39, pp.40-50,2017.

[2] James Austin, Howard Stevenson, Jane Wei-Skillern, Social and Commercial Entrepreneurship: Same, Different, or Both? Entrepreneurship Theory and Practice, vol. 30(1), pp. 1-22,2006.

[3] Wang Jingjing, Wang Ying. Review and Prospect of Foreign Social Entrepreneurship Research Literature.Journal of Management, vol.12(01), pp. 148-155,2015.

[4] Dees JG. Taking Social Entrepreneurship Seriously. Society. vol.44(3), pp. 24-31,2007.

[5] Leadbeater C. The Rise of the Social Entrepreneurship. London: Demos. Law, K, 1997. 
[6] Dorado S, Ventresca M J. Crescive entrepreneurship in complex social problems: Institutional conditions for entrepreneurial engagement. Journal of Business Venturing, vol.28(1),pp. 69-82,2013.

[7] Zhang Yuli, Wang Xiaowen. An Empirical Study of Prior Experience, Learning Style and Entrepreneurial Ability. Journal of Management Science, vol.24(03), pp. 1-12,2011.

[8] Tang Shuqin, Cai Li, Chen Wei. Review and Prospect of Entrepreneur Experience Research. Foreign Economics and Management, vol.36(1), pp. 12-19,2014.

[9] Siegel R, Siegel E, MacMillan I C. Characteristics distinguishing high-growth ventures. Journal of Business Venturing, vol.8(2), pp. 169-180,1993.

[10]Dovidio, J. F. Piliavin, J. A., Schroeder, D. A., \& Penner, L. (2006). The social psychology of prosocial behavior. New Jersey, US: Lawrence Erlbaum Associates Publishers.

[11]Batson C D, SHAW L L. Encouraging words concerning the evidence for altruism. Psychological Inquiry, vol.2(2), pp. 159-168,1991.

[12] Moorman, C., Miner, A. S. Organizational Improvisation and Organizational Memory. Academy of Management Review, vol.23(4), pp. 698-723,1998.

[13]Best S, Gooderham P. Improvisation: A legitimate strategy in the face of adversity. Small Enterprise Research, vol.22(1), pp. 49-68,2015.

[14]Robson PJA, Akuetteh CK, Westhead P, et al. Innovative income pursuit, human capital and business ownership experience in an emerging region: Evidence from Ghana. Small Business Economics, vol.39(3), pp. 1-23,2012.

[15]Zhang Xiuzhen, Zhang Kun. Previous experience and the willingness of social entrepreneurship the mediating role of self-transcendence values and risk propensity. Science and Science and Technology Management, vol.39 (02), pp. 142-156,2018.

[16]Hockerts K. Determinants of social entrepreneurial intentions. Entrepreneurship Theory and Practice, vol.41(1), pp. 105-130,2017.

[17]Zheng Xiaoying, Peng Yuqing, Peng Yu. "Da" is the best in the world? The influence of social comparison on prosocial behavior and psychological mechanism . Journal of Psychology, vol.47 (02), pp. 243-250,2015.

[18] Mair J, Noboa E. Social Entrepreneurship: How Intentions to Create a Social Enterprise Get Formed.Barcelona: IESE Business School Working Paper, No.521, 2003

[19]Leybourne S, Sadler-Smith E . The role of intuition and improvisation in project management. International Journal of Project Management, vol.24(6), pp. 483-492,2006. 